\title{
FEKETE-SZEGÖ INEQUALITY FOR GENERALIZED SUBCLASSES OF UNIVALENT FUNCTIONS
}

\section{LiAngPeng Xiong, Xiangdong Feng And JiAnliang Zhang}

Abstract. Let $\mathscr{P}_{\varphi}(n, b, \lambda)$ denote the class of normalized univalent functions $f(z)=z+a_{2} z^{2}+$ $\ldots$, which are defined in the unit disk $\Delta$ and satisfying $1+\left[\left(\lambda D^{n+2} f(z)+(1-\lambda) D^{n+1} f(z)\right) /(\lambda\right.$ $\left.\left.D^{n+1} f(z)+(1-\lambda) D^{n} f(z)\right)-1\right] / b \prec \varphi(z)$, where $\varphi(z)$ is the function with positive real part, $D^{n} f$ denotes the sălăgean operator, $n \geqslant 0,0 \leqslant \lambda \leqslant 1, b \in \mathbb{C}$. In this paper, for the class $\mathscr{P}_{\varphi}(n, b, \lambda)$, the Fekete-Szegö inequalities are completely solved. A more general class $\mathscr{K}(\beta, n, \lambda, g(z))$ related $\mathscr{P}_{\varphi}(n, b, \lambda)$ is also considered with same subject, which extends the earlier corresponding results for the class of strongly close-to-convex functions of order $\beta$.

Mathematics subject classification (2010): 30C45, 30C50.

Keywords and phrases: Univalent functions, sălăgean operator, starlike and convex function, close-toconvex function, Fekete-Szegö inequality.

\section{REFERENCES}

[1] H. R. AbDel-GaWAD, D. K. Thomas, The Fekete-Szegö problem for strongly close-to-convex functions, Proc. Amer. Math. Soc. 114 (1992), 345-349.

[2] R. M. Ali, S. K. Lee, V. Ravichandran, S. Supramaniam, The Fekete-Szegö coefficient functional for transforms of analytic functions, Bulletin of the Iranian Mathematical Society, 35 (2009), $119-142$.

[3] M. Darus, D. K. Thomas, On the Fekete-Szegö problem for close-to-convex functions, Math. Japon. 47 (1998), 125-132.

[4] E. Deniz, H. ORHAN, The Fekete-Szegö problem for a generalized subclass of analytic functions, Kyungpook Math. J. 50 (2010), 37-47.

[5] M. FeKete, G. SZegö, Eine bemerkung über ungerade schlichte Funktionen, J. Lond. Math. Soc. 8 (1933), 85-89.

[6] B. A. Frasin, M. Darus, On the Fekete-Szegö problem, Int. J. Math. Math. Sci. 24 (2000), 577-581.

[7] W. JANOWs KI, Some extremal problems for certain famlies of analytic ftmctions, Ann. Polon. Math. 28 (1973), 297-326.

[8] S. KANAS, H. E. DARWISH, Fekete-Szegö problem for starlike and convex functions of complex order, Appl. Math. Lett. 23 (2010), 777-782.

[9] F. R. KeOgh, E. P. Merkes, A coefficient inequality for certain classes of analytic functions, Proc. Amer. Math. Soc. 20 (1969), 8-12.

[10] W. Koepf, On the Fekete-Szegö problem for close-to-convex functions, Proc. Amer. Math. Soc. 101 (1987), 89-95.

[11] W. KoEPF, On the Fekete-Szegö problem for close-to-convex functions II, Arch. Math. 49 (1987), 420-433.

[12] W. MA, D. Minda, A unified treatment of some special classes of univalent functions, in: Proceeding of Conference on Complex Analytic, (Z. Li, F. Ren, L. Yang, S. Zhang, Eds.), Int. Press, 1994, $157-$ 169.

[13] A. K. Mishra, P. Gochnayat, The Fekete-Szegö problem for a class defined by an integral operator, Kodai Math. J. 33 (2010), 310-328.

[14] A. K. Mishra, T. PAnigrahi, The Fekete-Szegö Problem for a class defined by the hohlov operator, Acta Universitatis Apulensis. 29 (2012), 241-254. 
[15] Halit ORhan, ERhan Deniz, D. RǍducAnu, The Fekete-Szegö problem for subclasses of analytic functions defined by a differential operator related to conic domains, Comput. Math. Appl. 59 (2010), 283-295.

[16] Halit Orhan, ERhan Deniz, Murat ÇaĞLar, Fekete-Szegö problem for certain subclasses of analytic functions, Demonstratio Mathematica. XLV (2012), 835-846.

[17] A. Pfluger, The Fekete-Szegö inequality for complex parameters, Complex Variables Theory Appl. 7 (1986), 149-160.

[18] C. Pommerenke, Univalent Functions, in: Studia Mathematica Mathematische Lehrbucher, Vandenhoeck and Ruprecht, 1975.

[19] V. Ravichandran, A. Gangadharan, M. Darus, Fekete-Szegö inequality for certain class of bazilevic functions, Far East J. Math. Sci. 15 (2004), 171-180.

[20] G. S. Salagean, Subclass of Univalent Functions, in: Lecture Notes in Mathematics 1013, Berlin, Springer Verlag, 1983, 362-372.

[21] T. N. Shanmugam, S. Kavitha, S. Sivasubramanian, On the Fekete-Szegö problem for certain subclasses of analytic functions, Vietnam Journal of Mathematics. 36 (2008), 39-46.

[22] H. M. SRivastaVA, A. K. Mishra, M. K. Das, The Fekete-Szegö problem for a subclass of closeto-convex functions, Complex Variables Theory Appl. 44 (2001), 145-163.

[23] L. P. XIOng, X. L. LiU, A general subclass of close-to-convex functions, Kragujevac Journal of Mathematics. 36 (2012), 251-260. 